Full reference: Alshbili, Ibrahem, and Elamer, Ahmed Ahmed, "The influence of institutional context on corporate social responsibility disclosure: a case of a developing country".Journal of Sustainable Finance and Investment. Forthcoming (Accepted 30 ${ }^{\text {th }}$ September, 2019).

\title{
The influence of institutional context on corporate social responsibility disclosure: a case of a developing country
}

\author{
Ibrahem Alshbili ${ }^{\text {a }}$ \\ Consultant at the Libyan Audit Bureau \\ Email: abrhem200615@yahoo.com
}

\begin{abstract}
Ahmed A. Elamer ${ }^{b_{*}}$
Brunel Business School, Brunel University London, Kingston Lane, Uxbridge, London, UB8 3PH UK; and

Department of Accounting, Faculty of Commerce, Mansoura University, Mansoura, Egypt Email: ahmed.a.elamer@gmail.com

*Corresponding author
\end{abstract}

*Corresponding author: Brunel Business School, Brunel University London, Kingston Lane, Uxbridge, London, UB8 3PH UK, E-mail: ahmed.a.elamer@gmail.com. 


\section{The influence of institutional context on corporate social responsibility disclosure: a case of a developing country}

In this paper, we examine the influence of the institutional environment on the adoption of Corporate Social Responsibility Disclosure (CSRD) in Libya. In doing so, we use isomorphism as a neo-institutionalist theoretical construction that explores whether institutional factors act as pressures for CSRD practices. Using a qualitative method, the findings show that, despite managers perceive some coercive, mimetic and normative pressures interplay to influence CSRD, the revision of the firms' laws and policies and the establishment of CSRD regulations and monitoring institutions should be established and undertaken to improve accounting disclosure. The results propose important implications for adapting CSRD for firms and policy-makers in developing countries.

Keywords: Corporate social responsibility disclosure, Institutional context, Neoinstitutional theory, Isomorphism, Libya. 


\section{Introduction}

In recent years, the concept of Corporate Social Responsibility Disclosure (CSRD) has developed dramatically (Adhikariparajul et al., 2019; Ali \& Ruhaya, 2013; Mashat, 2005), and companies currently recognise that in order to survive and remain significant in the business world and gain intentional benefits, they must operate in a "socially responsible" manner, which requires a disclosure of their environmental and social information (Alnabsha et al., 2018; Alshbili et al., 2019; Deegan, 2002). However, a review of the literature shows that the level of CSRD practices is different between developed and developing countries, because developed countries have employed practical actions and procedures to push firms to reveal their CSR information (Barakat et al., 2015; Elmagrhi et al., 2019; Gerged et al., 2018). For example, while the UK government has appointed a CSR minister in the sectors of industry and commerce, France has passed a compulsory law where firms with 300 employees or more must draft CSR reports (Luetkenhorst, 2004). However, in developing countries, these initiatives have not encountered comparable interest (Jamali, 2007), because the institutions, economic development, standards and official systems that promote CSRD are fairly weak (Barakat et al., 2015; Kemp, 2001). The differences between developed and developing countries suggest that CSRD practice is largely affected by the institutional context in which firms operate. Consequently, this study examines the influence of the institutional context on CSRD practices in Libya, a mainly remarkable and valuable environment to study CSRD for a variety of reasons.

First, Libya has witnessed changes in its government regime, unlike developed countries, which are characterized by relative stability in their systems of governance (Eljayash, 2015). Therefore, the state and its institutional environment remain weak, with local and non-state actors driving the political transition, which could drive by a free media, and an emergent civil society (Boduszyński \& Pickard, 2013), and thus, the business environment has become more difficult and challenging. Second, Libya is a member of the organisation of petroleum exporting countries, and has the biggest oil reserves in Africa, which represent approximately $3 \%$ of the world's oil reserves, and therefore, is a vital contributor to the worldwide supply of 
sweet and light crude oil (Shareia, 2014). Therefore, firms that work in this sector are highly risky in terms of employee health and safety conditions and environmental repercussions (Jackson \& Apostolakou, 2010).

We respond to a number of calls for further investigation of contextual and institutional factors in developing countries such as Libya (Islam and Deegan 2008; Belal et al., 2013; Tilt 2018). The study utilises DiMaggio and Powell $(1983,1991)$ framework to explore the factors that influence the adoption of CSRD practices. DiMaggio and Powell $(1983,1991)$ show that firms may respond to three types of pressures. For instance, coercive pressure stems from both informal and formal pressures applied by powerful actors such as the government (DiMaggio \& Powell, 1983, 1991), while mimetic pressure arises primarily from uncertainty in the environment. Normative pressure covers both norms and values that defend how different actors should behave (DiMaggio \& Powell, 1983, 1991).

To date, the CSRD practices reported by Libya firms, the relevant pressures they receive from governmental organisations or their parent companies (if any) and, most importantly, the motivations behind their CSRD practice, are still under-explored in the literature. This study aims to fill this gap in the literature by addressing the next two research questions.

- To what extent do external institutional pressures influence the adoption of CSRD practices in oil and gas firms operating in Libya.

- What are the specific drivers (external and internal) and the obstacles that act as major impediments to their further development in the oil and gas firms working in Libya?

In order to answer these research questions, the article studies CSRD practices by seeking the relevant perceptions of managers and policy and decision makers within the NOC through interviews. The interview method was considered to be suitable as the research involved access to the appropriate experiences and knowledge of the managers of oil and gas firms and the policy and decision makers within the NOC regarding their own CSRD practices (O'Dwyer, Unerman, \& Bradley, 2005). We collected interview data using in-depth semi- 
structured interviews of 14 senior managers of oil and gas firms and 6 policy and decision makers within the NOC in Libya, to establish their motivations in relation to CSRD. Due to the cultural, economic and political setting of Libya, in-depth semi-structured interviews enhance our understanding of CSRD that involves managers, and various stakeholders.

The importance of our study is to facilitate our understanding of the problems of CSRD in less developed countries, which cannot be devalued since the majority of the world's population lives in developing countries that have unique social, cultural, political and environmental characteristics (Fifka 2013; Tilt 2018; United Nations 2013). Understanding the problems and the context in which CSRD issues occur can improve policy, provide better support and provide adequate supervision to encourage better CSRD outcomes. Likewise, in the Middle East, particularly in Libya, there is very limited knowledge about disclosure to a large extent and the drivers of, and barriers to, CSRD more specifically. Similarly, the lack of civil rights, weak NGOs and free press indicate that the mechanisms to promote CSRD should affect these complex, and regularly inconsistent, drivers. To do this, a better understanding of Libya and its context is needed. Due to cultural, economic and political differences in Libya, the only way to recognise, and advance, CSRD is to perform fieldwork that involves managers, professionals, and various stakeholders. This study could possibly initiate knowledge that can help improved policy and motivations for firms to both involve in, and disclose on, CSR. In such an exceptional context with enormous natural wealth that is subject to the highest levels of ruin (Kwansah-Aidoo 2007), accounting and reporting is a vital tool for policy-makers.

This article is organised as follows. Section 2 provides background information about Libya, followed by a discussion of isomorphism and a review of the literature in Section 3. Section 4 highlights data collection and data analysis techniques. The article then proceeds with the presentation of the empirical results in section 4, while section 5 deals with the discussion and contribution of the research. The final section concludes the article. 


\section{Libya - A brief profile}

Libya is an Arab country, geographically located in the north central part of Africa. It occupies an area of 1,759,540 $\mathrm{km}^{2}$, which is comparable in size to the state of Sudan (World Bank, 2016). Libya was the first country to achieve autonomy through the United Nations and one of the first former European possessions in Africa to gain independence on December 24, 1951. Libya shares common borders with Tunisia and Algeria in the west, Egypt and Sudan in the east, Chad and Niger in the south, and the Mediterranean Sea in the north. In 2014, the population was 6 million, and the official language is Arabic. The Ottoman Turks took control of the country in 1551, and the colonization continued till Libya achieved independence in 1951. After leading the country for 18 years, King Idris al-Sanusi was overthrown in a successful military coup in 1969. Subsequently, Libya was ruled by Qadhafi until October 2011, who was then violently murdered in 2011 during widespread protests that escalated rapidly into a national popular rebellion. Although the General National Congress, a parliament dominated by Islamists, located in the western region, ruled the country legitimately until June 25, 2014, refused to recognize its most liberal successor, the House of Representatives, located in the eastern region. This caused each parliament to have its own government. While the UN has been working to reconcile governments and encourage them to form a national unity government (The World FactBook, 2016), the two parliaments have failed to compromise and reach political agreements until now.

In order to regulate the business environment, the state of Libya has created institutions and several laws that were expected to have a great impact on accounting practice. The constitutional regulations of a country can indirectly or directly have influence its corporate reporting and disclosures practice (Hawashe, 2014). Table 1 presents the institutions, laws and key aspects of them, and shows that that the NOC seems to exert pressure on companies, not only to follow their reporting guidelines, but also specifies the type of information they need to report on. The firms' management practice, therefore, would have to take into account the NOC's aspiration and gain the support of such an authority, since it could not merely help legitimise corporate operations, but also allow access to additional resources. Despite this, the 
other legal and regulatory framework in the country do not make any reference to CSR information or its disclosure, therefore significant shortcomings in the regulatory framework and legal system and the lack of environmental remediation facilities continue being key issues.

\section{INSERT TABLE 1 ABOUT HERE}

\section{Theoretical underpinnings and literature review}

The neo-institutional theory (Elamer et al., 2017; DiMaggio \& Powell, 1983; Meyer \& Rowan, 1977; Scott, 1987, 2014) explains how firms accept and respond to the alteration of institutional and social pressures and anticipations to sustain legitimacy. It focusses on the behaviour of companies who are motivated by pressures in broader society, and focuses on the behaviour of companies motivated by pressures in a particular institutional milieu, by accommodating to norms and rules that are highly respected by the society (DiMaggio \& Powell, 1983, 1991; Greenwood et al., 2013). DiMaggio \& Powell (1983, 1991) offer a framework of three distinct, interrelated, and equally reinforcing institutional pillars - the coercive, normative and mimetic pillars, which are valuable in analysing institutional pressures on companies. Because it is important that companies achieve and maintain legitimacy in the environments in which they operate, they may experience different pressures to adopt specific practices and become isomorphic with the institutional context in which they operate (Kostova \& Roth, 2002). Coercive pressure stems from both informal and formal pressures applied by powerful actors, such as the government, on which the firm dependents. This pressure can occur in the form of invitations, persuasions or orders to change and adopt a particular organisational practice (DiMaggio \& Powell, 1983, 1991). Informal pressures include codes of conduct, monitoring and guidelines, while formal pressures include regulations and laws (Kim et al., 2013). To avoid punishments, companies act in response to these pressures and implement the necessary organisational practice (Greenwood et al., 2013). 
The normative pillar influences values (which in a social context is acceptable to follow) and norms (how things should be done). In other words, it highlights the conventions and actions that are legitimate for society by acting in a way they expect and consider suitable and ethically accurate (Scott, 2014). The mimetic pressure arises primarily from the ambiguity within the environment, which leads a company to imitate other fruitful companies (DiMaggio \& Powell, 1983, 1991; Greenwood et al., 2013). Consequently, companies achieve legitimacy in their environment may raise their opportunities of success and survival by conforming to such pressures (Grecco et al., 2013; Kostova \& Roth, 2002). Therefore, mimetic isomorphism could be considered a reaction to organisational questionability by pursuing the best course in practice. In other words, the pressure of this mimetic pillar is to identify and compare the most excellent practices in the field, so that the copy of these practices arises as a result of their institutional approval. Consequently, companies achieve legitimacy in their environment and increase their chances of success and survival by adjusting to such pressures (Grecco et al., 2013; Kostova and Roth, 2002). This is important to protect the reputation of companies and ensure their continued existence.

The coercive pressures for CSRD directly influence the CSRD activities of companies through government regulations and rules (Othman et al., 2011). Each government creates its own monitoring pressures on CSRD, facilitating or endorsing specific practices (Pedersen et al., 2013). For example, while the UK government has appointed a CSR minister in the Industry and Commerce sectors, France on the other hand has passed a mandatory law where firms with 300 employees or more must write CSR reports (Wanderley et al., 2008). However, in developing countries, these initiatives have not found comparable interest (Jamali, 2007), because the institutions, and legal systems that promote CSRD are somewhat weak (Kemp, 2001). Despite this, global pressures could influence firms to adopt CSRD practices in developing countries. For example, global codes, such as the Global Reporting Initiative, ISO reporting requirements, could make firms respond to these pressures in order to obtain "legitimacy" with their peers. 
The normative pressures for CSRD practice must also respond to the social norms, values and expectations of society (Grecco et al., 2013). Compliance with social expectations contributes to the organisational survival and success. While in many countries what motivates businesses is to make a profit, in other countries, a social rationalisation is needed to achieve that goal. For example, in North African countries, it is estimated that companies reflect the values of the economy and the diligence of the East, and value social development more than singular needs. Uncertainty could also constrain business activity (Setyorini \& Ishak, 2012). CSRD practices policies and behaviours in many developing countries are based on national and social traditions (Welford, 2005). However, due to the fragile state of the institutional environment in some developing countries, some companies may tend to mimic the performance, structure and practices of other companies that are perceived as more successful in terms of CSRD practice (Grecco et al., 2013). As such, firms use CSRD as a means to participate in and responding to institutional pressures.

Empirically, Belal and Owen (2007) find that firms disclose their CSR information due to the perceived pressure of external forces, particularly parent companies' instructions and demands from international buyer. However, while Amran and Devi (2008) and Othman et al. (2011) found that regulatory efforts are a significant means to support CSRD practices in Malaysia, in contrast, Setyorini and Ishak (2012) found that under the uncertainty of the Indonesian government instrument for CSRD practice, firms seem to mimic structure, practice and performance from other successful firms. Pedersen et al. (2013) show that while it was found that government coercive pressures influence the practice of the CSRD, the firms that report for the first time were motivated by other firms, guidelines, and standards. Additionally, although Hossain (2012) found that firms engage in CSRD practice to help them build better relationships with government and society, Beddewela and Herzig (2013) found that subsidiary firms in Sri Lanka are prodigiously motivated by their need to achieve internal legitimacy and comply with the formal institutionalised processes to report CSR. Belal et al. (2015) found that promoting social welfare motives, gaining publicity, and influence of GRI and ISO 26000 are key motivations for the Islamic Bank Bangladesh to engage in CSR 
reporting, but Zhao and Patten (2016) improvements in the image, mainly related with public interaction to influence CSRD in China.

It is clear from the above review that there is no single motivation, per se, to disclose CSR information. On the contrary, institutions, regulations and culture, which vary in many countries, are significant in the monitoring firms' actions and the effective enforcement of standards related to CSRD (Dhaliwal et al., 2014). Therefore, understanding the moderating influence of a country's factors on CSR may not simply help to put the conclusions of the CSR literature in the right perspective, but it can also provide new insights into the problems related to CSR. As such, based on the review of the above theoretical and empirical literature, this research expects to fill three key gaps, which are: a) limited empirical studies that examine the influence of the specific institutional setting on the adoption of the CSRD in the North African context, b) limited empirical studies (Amran \& Haniffa, 2011; Beddewela \& Herzig, 2013; Belal \& Owen, 2007; Zhao \& Patten, 2016) applying neo-institutional theory to examine the factors that influence CSRD in a developing country context, and c) overcoming a major weakness in existing Libyan studies (i.e. Mashat, 2005), which lack a theoretical underpinning and are conducted outside of the oil and gas sector. Consequently, this research seeks to utilise isomorphism as a neo-institutionalist theoretical construct that explore whether institutional factors act as pressures for CSRD practices (as shown in Figure 1).

\section{INSERT FIGURE 1 ABOUT HERE}

For decades, organisational approaches and behaviours have been designed according to social requirements and pressures (Fernández-Allés and Valle-Cabrera, 2006). Based on this argument, the response to the external and internal context in which firms work and maintain their acts and behaviours is critical to their existence (Dacin, 1997, Fuenfschilling and Truffer, 2014). On the one hand, the institutionalisation of norms, values and structures and social behaviours arises from formal and informal processes between internal groups within the 
company (DiMaggio and Powell, 1991). On the other hand, the external context is cogitated vital with regard to the probability of launching a number of relations between the firm and the regulations and rules of the regime, professional organizations (authorisation and certification) and other organizations, particularly those that are in the same industry (Barrena Martínez et al., 2016).

DiMaggio and Walter (1983) depicted isomorphism as: "a constraining process that forces one unit of population to resemble other units that face the same set of environmental conditions". Dillard et al. (2004) illustrated it as: "Isomorphism refers to the adaptation of an institutional practice by an organization". Thus, isomorphism denotes to the process (DiMaggio and Powell 1983) by which the companies adapt institutional practices (e.g. CSRD) of other organisations (Dillard et al. 2004).

These three contributions of isomorphism, described within the approach of the original institutionalism, help describe why organisations consider that the imitation of recognised behaviours in their environment is capable of confirming the legitimacy of the groups and institutions that comprise it. However, the new institutional development, considered as neoinstitutionalism, proposes that organisations and their policies be significantly affected by cultural variables, legal, historical and political institutions that describe detailed forms of behaviour for several countries (Doh \& Guay, 2006, Powell \& DiMaggio, 2012). Neoinstitutional theory suggests that firms require to adapt their CSR practices that mimic the key formal institutions (e.g. policies, laws or/and private arrangements) and informal institutions (e.g. cultural heritage, customs, religious beliefs or professional routines) since they will not able to survive without a particular level of external social support (e.g. Barrena-Martínez et al., 2016; Jamali et al., 2017; Frynas \& Yamahaki, 2016).

Our theoretical model is based on neo-institutional theory and presumes that formal and informal CSR institutions may form the CSR disclosure agenda in developing countries such as Libya in a similar way to what they evidently do in developed ones (see Campbell, 2004, 2007; Deegan and Blomquist, 2006; Hiss, 2009; Perez-Batres et al., 2012). In details, the neo- 
institutional lens offers strong evidence that the disclosure of CSR may be improved by a series of institutions and various types of isomorphisms (e.g., Gallego-Álvarez and QuinaCustodio, 2017). We precisely explore the impact of formal and informal CSR institutions on adoption of CSRD. Particularly, we follow earlier CSR disclosure literature such as PerezBatres et al. (2012), Deegan and Blomquist (2006), and Sumiani et al. (2007), which revealed that the disclosure of CSR is shaped by institutions that support CSR. In summary, the motivations of firms towards CSRD may be inclined by the coercive, mimetic and normative isomorphism in the institutional environment of Libya. Figure 1 represents a model of the hypothesized pressures to adopt CSR disclosure.

\section{Method}

A qualitative approach was used to explore the pressures and factors that influence CSRD adoption, which is specifically suitable for examining factors that are not formerly codified or perceived (Siggelkow, 2007). Due to the nature of qualitative data, which is different from quantitative data, its validity and reliability depend greatly on the gathering of data and the process of analysis (Hesse-Biber \& Leavy, 2011). As such, one of the key challenges in qualitative research is to ensure that the collection of data and its analysis meets the tests of validity and reliability (King \& Horrocks, 2010). Consequently, to achieve transferability and credibility (external and internal validity), dependability (reliability) and conformability (objectivity) in its results, the researcher followed the criteria as proposed by Lincoln and Guba (1985) and Silverman (2011).

Credibility refers to extent to which the interpretation of the investigator is authorised by those with whom the study was accomplished (Lincoln \& Guba, 1985). As this study was carried out only by us, credibility was obtained by ensuring that the access quality was achieved by us to companies and by maintaining a complete record of the study through having a research diary about the interviews undertaken. Transferability, which replaces generalizability, refers to the investigator's ability to provide sufficient details so that the reader can consider to what extent the conclusion drawn in one environment could be transferred or that makes 
transferability judgments possible to another environment (Lincoln \& Guba, 1985). The criteria in this research were addressed by giving details linked to the participants, the interview procedures, transcription and following analysis of the data gathered.

Dependability, which replaces reliability, refers to the degree of constancy in the study settings, so that the study can be replicated elsewhere (Lincoln \& Guba, 1985). A qualitative research in general assumes that real-world settings unavoidably alter, and replication is therefore not achievable. The necessity, thus, in qualitative studies, is to show that the investigator has taken into consideration the natural unsteadiness of the facts they are researching. However, with the intention of increasing the reliability of the interviews, Silverman (2011) proposes three key criteria. First, the development of interview guidelines in an obvious and understandable way for the interviewees should be considered. Secondly, in order to make the results more dependable, precise taping and transcribing is needed. Finally, inter-coding reliability requests are to be sustained. Therefore, it is significant to stay away from any uncertainty when data is coded, such as the overlap between the coding groupings or errors of simple coding. As such, the dependability of this research was obtained through multiple stages of coding the data, ensuring the robustness of the study results.

Finally, the conformability, which replaces neutrality, refers to where the researcher should present adequate details regarding the data gathering process and analysis, so that it is obvious to a reader how the investigator may have arrived at a particular conclusion (Lincoln \& Guba, 1985). Thus, in this study, the conformability was obtained through providing full details linked to all phases of gathering the data, with real evidence of the gathered data, in addition to the stages of the data analysis. In addition to this, Louise and While (1994) claim that an interviews' validity is established by the extent to which participants are keen to offer a wellinformed data in which this research involved a careful selection of interviewees.

\subsection{Data Collection}


The data were obtained from 20 in-depth semi-structured interviews conducted with two groups. The first group were the managers of the oil and gas companies that were in a position to deal with the demands / pressures to disseminate CSR information (see table 2). These managers were selected due to their persuasive influence on corporate disclosure (Ntim et al., 2015). The second group were regulators and policy makers within the NOC that were identified by company managers as the body responsible for pressuring companies to disseminate CSR information (see table 3). The selection of the interviewees was based on the agreement of the interviewee in the will to be interviewed and their knowledge on the subject (Bailey \& Peck, 2013). The process of conducting the interviews was carried out through several steps. Consent forms were given to both groups to sign as an agreement that they had agreed to contribute to the investigation. Each interview was conducted in each company or organization and the questions that were used were open questions, that is, how / why / what / to what extent, to obtain as much data as possible. A total of 14 internal actors and 6 external actors were performed in 13 weeks, from September to December 2014, using the Arabic language and varied between 43 and 78 minutes. Secondary data was also collected during the same period.

\section{INSERT TABLE 2 ABOUT HERE}

\section{INSERT TABLE 3 ABOUT HERE}

\subsection{Data Analysis}

Data analysis was performed in four stages. The first stage was to transcribe each interview in Arabic in a notebook document similar to a global Microsoft 2013 document (King \& Horrocks, 2010). The average duration of each interview transcript was around 8 to 10 pages. Miles and Huberman (1994) said that before ordering and examining the data collected, the researcher needs to familiarize himself with his data. Therefore, the second stage consisted in 
carrying out a microanalysis of each interview, to understand any invisible meaning within the paragraphs, sentences and words. A translation of each interview was made from Arabic to English as the third stage and a great effort was made to preserve the original meanings in each case. The final stage was to transfer and order all interviews as a project in NVivo 10 software. Secondary analysis has begun for both actors by developing a code system to classify the data through the thematic analysis technique as recommended. by King and Horrocks (2010). The coding of the thematic analysis involved reading and rereading the transcript of the interview looking at patterns of topics in the entire data set based on the research question and the predefined variables. This process was carried out through two main stages as suggested by King and Horrocks (2010); the descriptive / initial coding stage, the interpretive coding stage (see table 4 ).

\section{INSERT TABLE 4 ABOUT HERE}

\section{Findings}

\section{Institutional Factors Influencing CSRD}

\section{The Influence of the NOC}

Although there are no legal requirements for the CSRD in Libya, this investigation observes how the Libyan state through its governing body, the NOC, exerts informal pressure on oil and gas companies to follow their reporting guidelines (i.e., HSE.GDL.001.00 and HSE. PRO.002.00). This is evident by the managers of several companies that emphasized that they follow the NOC guidelines in terms of making their annual reports. Although the NOC acts as a government institution that has the coercive authority of the state to control the behaviour of the lower social actors that they understand at the organizational level, the absence of strict and complete strict regulation can act as a barrier. However, because any oil and / or gas company that wishes to operate in the Libyan oil and gas industry has to obtain a license from this authority and allow periodic checks to be carried out, obtaining the support of that 
authority may not only help legitimize corporate operations, but similarly allows access to additional resources. A manager of a local company explains this tension well:

"[...] our activity of social responsibility disclosure is guided by the National Oil Corporation from overseas training, medical insurance, and employment of graduates to occupational health. All kinds of social activities at the moment are prepared by us as influenced by National Oil Corporation. [...]”

(Financial Manager, Local Company One, 2014)

Although the CSRD was of low importance within the old regime, the post-government war through its governing body, the NOC, began to take the social and the environmental seriously, when they established a sustainable development department in All rules (NOC, 2012) to encourage companies to participate in CSR and its dissemination. Since most of the local oil and gas companies are public companies, and due to the close connection with the government (because they are owned by the NOC), they need to balance the profit objective with the NOC reporting guidelines, including the agenda of the CSRD. A joint venture manager comments:

“Actually, the majority of our company's annual reports and other local companies are similar in terms of style, because they are guided by the National Oil Corporation monitoring and reporting requirements, a few other companies might fancy reporting a bit more, yet we report based upon the requirements from the National Oil Corporation [...]"

(Head of Health, Safety and Environment, JV Company One, 2014)

While the post war government has reiterated its willingness to meet certain social and environmental expectations by providing guidelines for social responsibility reports after 2011 (see table 5), such guidelines are a voluntary initiative. The purpose of these guidelines is to effectively communicate current social responsibility to the NOC headquarters to ensure 
compliance with internal pressures and obtain internal legitimacy. Therefore, companies must align their decisions with government aspirations, which is significant for their continued existence. Through its activities, the dynamics of field coercion comes into play. As a manager of a local company says:

"We now have guidelines from the National Oil Corporation and minimum reporting requirements of HSE data, [...] the National Oil Corporation is our customer and it's a governmental body, [...] We need to follow their guidelines and report the social and environmental information that are required"

(Environmental Manager, Local Company Four, 2014)

One external actor confirms such pressure and adds:

"[...] we have [established] monitoring reporting requirements to report environmental data, safety data, and health data, as well as energy data. So the local companies are required to provide [....] reports about their activities whether they are social or financial $[\ldots]$ ”,

(Interviewee Four, NOC, 2014)

INSERT TABLE 5 ABOUT HERE

The nature of the CSRD differs between countries, and even more between developed and developing nations (Belal and Momin, 2009; Imam, 2000). Our study shows that the main driving force of the CSRD that emerged appeared to be regulatory requirements and government effect. The promotion of NOCs was also supposed to be an important driving force. Government effects and regulators as drivers of CSRD have been demonstrated in several studies in different countries (Kuasirikun, 2005; Wilmshurst and Frost, 2000; Kolk, 
2003; Harvey and Schaefer, 2001). For example, Rowe and Guthrie (2010) interviewed senior managers of 15 companies in China and identified the government's coercive institutional participation as the main driver of CSR initiatives and reports. From a theoretical neoinstitutional point of view, the regulatory effect of the Libyan government is coercive isomorphism that forced companies to respond to government regulation and other pressures.

In conclusion, the previous findings show that NOC, as a social institution, has the coercive authority of the state to control the behaviour of companies. The adoption of government requirements and policies by companies, especially those owned by the state, seems to be the result of the need to appear legitimate to continue their long-term survival and obtain internal legitimacy from their central office. By meeting the minimum requirements through the dissemination of social and environmental information following established guidelines, oil and gas companies expect to represent and improve their reputation in the eyes of the state. In this case, the government seems to play an important role, especially in the post-2011 changes, where a series of policies and guidelines have been introduced.

\section{The Influence of Overseas Partners}

Although the NOC has established reporting guidelines for CSRD, local companies have been exposed to and are greatly influenced by western management style. This finding is most evident where local companies who operate in the oil and gas industry with a joint venture status have progressively complied with their foreign partner standard and regulations such as the ISO 14001, and OHSAS 18001 certifications and polices. The majority of the foreign partners come from developed countries such as the US, Italy, Canada, and France, thus, these firms are pressurised by the market to conform to the standards of CSR signalling their home countries' influences. The Director of Finance from foreign company two remarks about this tension clearly:

"[...] local firms with a foreign partner are more driven by their foreign partner

to disclose social information. They are subject to additional reporting 
requirements from their foreign partner, and usually under pressure. Foreign companies usually have shareholders. They always pursue attracting new investors; consequently, more accurate and reliable social information is disclosed"

(Director of Finance, Foreign Company Two, 2014)

Indeed, Libyan companies rely heavily on foreign companies in terms of technological assistance. Therefore, the reason why the local companies behind entering the joint venture is undoubtedly to optimize the benefit of merging the experience and technical capabilities of their partners abroad. However, for foreign partners to enter the country, they must have a national investor entitled to government support and assistance. Therefore, there is some kind of coercive, if not mimetic, pressure on Libyan companies to integrate institutional practices such as CSRD. The data analysed shows that local companies that are in a joint venture state described how, although their owner did not order the adoption of the CSRD, they were influenced by the reporting style of their foreign partner. In this regard, the Head of Accounts and Budget of a joint venture explains:

"We work here in a partnership with [...]. We follow our partner's reporting style. They have a good reporting system. We follow this reporting trend, in order to be considered as a world class company"

(Head of Accounts and Budget, JV Company Five, 2014)

This mimetic isomorphism was also implemented to clarify the results of some other CSRD studies. For example, Amran and Siti-Nabiha's (2009) proposed that the key motivation of Malaysian companies for CSRD was to emulate their counterparts in developed countries. Aerts and Cormier (2009) described that mimetic and coercive isomorphism motivated imitation within the industry in the environmental information practices of companies in Canada, France and Germany. In addition, de Villiers and Alexander (2014) show a 
remarkable similarity in the CSRD structure of mining companies in Australia and South America; The companies seemed to use global patterns such as the GRI to form their CSRD, and increase the details by denoting national regulations, standards and specific local stakeholders. The results were explained using mimetic, normative and coercive isomorphism.

\section{The Influence of Foreign Owned Firms}

The ambiguity and fragile state of the Libyan institutional environment make it easier for business managers to mimic the CSRD strategy of other companies to be more legitimate and successful in order to be accepted as part of a wider global network. This pressure is most evident when there is no legal requirement for the practice of CSRD. Although the NOC has guidelines for reporting, local companies operating in the oil and gas sector seem to have difficulties in disseminating social and environmental information. While Libyan society assigns companies responsibility for disseminating CSR activities and avoiding state sanctions, Libyan managers respond to such pressures by imitating competitors of their foreign companies. Two local managers working at senior management level illustrate:

“[...] we just look at how other foreign oil and gas companies like [...] oil and gas company include this information in their reports, and we just follow them, and those are the key guidance for us"

(Quality Manager, Local Company One, 2014)

"[...] what we do is, we take good international companies who are good annual report reporters, and see how they report, how they present their information, and we use them as our guidelines; of course there are things that we cannot copy, but we want to be good too"

(Accounts Manager, Local Company Two, 2014) 
In this regard, foreign owned companies usually come from developed countries, like Germany, the US, and the UK and they are more concerned about the disclosure of CSR information because they usually have diverse knowledge and values to raise their strategic decisions in regards to public and social activities. Therefore, in order to appear legitimate to the state among other stakeholders, these firms tend to communicate their CSR activities. In this way, local companies, as revealed by the analysed data, imitate to some extent the behaviour of these foreign companies in terms of reports to disclose part of their CSR information. The following quotes are illustrative of this:

"We are motivated by the practice of foreign owned companies. These companies are successful. We do not have regulations and laws regarding the disclosure of social and environment impacts here. So we follow the practice of other foreign companies"

(Accounts Manager, Local Company Two, 2014)

"Companies that are owned by foreigners influence considerably on local companies' corporate behaviour. They are influenced by the western management style. Wherever they go they report and disclose their activities. They are successful".

(Environmental Manager, JV Company Four, 2014)

\section{The Influence of Cultural Factors on CSRD}

The adoption of CSRD by companies operating in the oil and gas industry of Libya is also driven by pressures derived from the need to maintain the reputation and pressures of the company to meet the expectations of society. This is evident by several managers who identified these factors as social drivers for CSRD. Some of the main oil and gas managers interviewed perceived the reputation and image of a company as the main driver to adopt CSRD, while working within society. Most oil and gas companies embark on practices of 
dissemination of environmental and social responsibilities in response to their personal convictions of doing something for the community. In fact, participation in CSRD practice is more likely to promote a company's reputation and image to become a better business. In this case, the finance director of the foreign company two and the quality manager of the local company, respectively commented:

“Our driving force is improving our company's reputation and image, and its value in the market. We have to present a good image to the government [...], and to our employees. This will lead to increase in the level of satisfaction of our employees, thus increasing their devotion and their integration within our company"

(Director of Finance, Foreign Company Two, 2014)

"It's our reputation. As you know, reputation is built based on company's history, ethics, morality and its public image. One way of keeping this reputation, $[\ldots]$ is through participating in social activities, letting the public know about it, and so a positive image is created"

(Quality Manager, Local Company One, 2014)

The public relations strategies developed by companies in Libya to increase the trust of stakeholders in them reflect how they reconcile these pressures. Companies in Libya focus on issues such as the justification of their existence within society through an upward approach not only to focus on government relations, but, more significantly, to build trust and longterm relationships with local residents. As such, the cultural and social norms of Libya would lead us to anticipate the explicit CSRD, but they are still hidden. Given the complex pressures, CSRD practice remains predominantly normative in response to the country's national systems and interests. In this case, it became clear that several interviewees highlighted how important 
public expectations are and how important they should be to meet their needs when making immediate CSRD decisions:

"The public have expectations from us; we need to communicate our occupational health and safety information. We need to show a good treatment of the local communities and being friendly with the environment [...]. If we, as a company, do not meet these expectations which are always changing, our existence will be threatened. Thus, one way of meeting these expectations is through a disclosure channel of our social activities"

(Environmental Manager, JV Company Three, 2014)

In addition, several respondents attributed the social obligation as one of the key drivers of the adoption of the CSRD practice. As a country, Libya continues to rely heavily on oil revenues, therefore, oil and gas companies have voluntarily integrated into the disclosure element, proactively boosting bidirectional communications to respond to the concerns raised by society. In many cases, the practice of CSRD goes beyond compliance with legal requirements, and companies recognize the need to understand how their activities interact with sensitive environments. Managers, therefore, emphasize that compliance with the social obligation is a key factor of CSRD in Libya. For example, the Head of Health, Safety and Environment of a two joint venture explains:

"I believe in social obligation. As a company, we work in a sensitive environment that has an effect on the environment and people who live nearby the oil fields; everyone knows this. So the company's commitment is to do something for this community. Today we do make profit; we should share some of it with the society, because as a company we won't be affected much"

(Head of Health, Safety and Environment, JV Company Two, 2014) 
These results are supported by Momin and Parker (2013). They studied the CSRD incentive by interviewing 39 managers in multinational corporation (MNC) companies listed in Bangladesh. Their article is the first extensive work on the motivation of the CSRD of MNC subsidiaries in Bangladesh. They used several theories, integrating institutional and neoinstitutional theory, and propose that a desire for internal legitimacy arises as the main motivating influence for CSRD practices, while the contextual characteristics of the external host country limit such practices in Bangladesh. Jamali et al. (2009) in the context of the Middle East show that CSRD varies among countries because of different cultural and institutional realities. As Deegan and Unerman (2006) argue, accounting practices cannot be secluded from culture, human and social institutions, it is culturally determined. Therefore, cultural customs, values, beliefs and norms impact CSRD.

In summary, a more visible and open corporate culture has begun to emerge for oil and gas companies in Libya, and this has allowed CSRD to integrate even more as a critical part of their business, mainly because they want to succeed in the context. Libyan Cultural factors, highlight some interesting points. While the pressure of cultural factors is evident, to see the explicit CSRD in Libya (that is, the social normative pressures that arise from social obligations and the reputation and image of companies), a more complex dynamic of " powerlessness" to influence organizational change in a fragile state is evident as well. By uniting these types of cultural factors, local legitimation pressures, demonstrated in the form of normative pressures, can clearly explain why these companies adopt CSRD in the first place. However, what is evident from the analysis is that there is a growing awareness of the CSRD in Libya both among trade associations and between companies.

\section{Other Factors Influencing CSRD}

The interview analysis also indicates that firms of foreign investors operating in the Libyan oil and gas industry are forced by the reporting culture of their parent company from an internal perspective. Most foreign companies come from developed countries such as

Germany (in the case of Wintershall) and France (in the case of Total), etc., where social and 
environmental awareness is high. Therefore, such companies usually implement accounting practices and a dissemination culture similar to the parent company, since they share comparable policies and missions. This can be seen as crucial for the survival of a subsidiary, as a consequence of its dependence on the parent company for continuous access to resources such as technology, knowledge and capital. This suggests that the CSR practices of foreign companies are influenced by international stakeholders, moderated by the parent company's policy, to a greater extent than only local stakeholders in Libya:

"We are a subsidiary of [...] company. [...] has an excellent social and environmental reporting system. We follow the reporting culture of the parent. We share the same policy, the same social responsibility policy"

(Head of Health, Safety and Environment, Foreign Company Three, 2014)

"For us, we disclose our social information, because our parent expects us to disclose this information to become more efficient. We need to confirm the demands and expectations of our parent. Otherwise we would be in trouble. So we follow $[. .$.$] our parent, and this is our main guidance"$

(Director of Finance, Foreign Company Two, 2014)

The data analysed from the interview also show that the activities of large and old companies are of interest to many interested parties and these factors are considered important in influencing the practice of the ERSC. The large size reflects higher levels of CSRD, what the government wants, and age has the advantage of institutional relationships built over time with external institutions that companies can use for their benefit. These factors are important attributes, because they shape the internal capacity and behaviour of companies, while simultaneously interacting with the external environmental context to shape the behaviours and performance of companies. Large and old companies, as the main managers observe, face different pressures in Libya, because they are more visible in the eyes of the government. 
Therefore, these companies disclose more information about CSR on purpose. Two managers express this tension well:

"We are a large company in terms of size; we need to engage more in social responsibility activities [...] than small firms. We have to provide high level of disclosure, because we are more visible in the eyes of government, and have more impact on the community. Other large firms practise disclosure and therefore, we need to be like them and disclose more than unknown small companies"

(Director of Finance, Foreign Company Two, 2014)

"The level of CSRD differs between new firms and old firms, because other circumstances such as experience in the market play a very crucial role. We are new company. We look at new firms; they do not disclose much of this information. Old firms do and get more advantages from disclosure than new firms. New firms usually struggle about how to even report, so usually they use basic reporting style"

(Auditor, Foreign Company Four, 2014)

The auditor of local company one confirms such pressure and adds that the influence of the firm's age on the extent of CSRD practices can just occur in the first few years of the life of the firm. As the company gets older than five years, the firm would gain sufficient skills and become knowledgeable about involvement of CSRD, therefore, it will become like other old companies:

"The influence of age is normally during the first five years, because new companies usually have new staff and equipment, but they do not have enough experience regarding how to disclose social and environmental information. 
However, after five years' time, I do not see any impact of the age on the level of CSRD”

(Auditor, Local Company One, 2014)

\section{Discussion}

This research aimed to explore whether institutional factors act as pressure for the adoption of the CSRD. Although the results show that the NOC, foreign business partners, the behavior of the activities of foreign-owned companies, the parent company factor, the size and age of the company, the need to maintain reputation and Company pressures to meet the expectations of society interact to influence CSRD in the Libyan context, these factors can be discussed within the framework of neo-institutional theory (DiMaggio and Powell, 1983, 1991), classifying and evaluating coercive pressures, regulations and mimetics on the practice of CSRD in Libya.

Coercive pressures generally come from both informal and formal pressures applied by powerful actors, such as the government. Informal pressures may include guidelines and codes of conduct (DiMaggio and Powell 1983, 1991). In Libya, there are no legal requirements for the CSRD, but there are guidelines available made by the NOC. Although respondents highlighted the NOC as the main reference in the preparation of their annual reports to achieve the internal legitimacy of their central office, previous existing studies (Alshbili, 2016; Mashat, 2005), found that the level of CSRD was generally low and unsatisfactory. This can be attributed to the lack of regulations and regulatory agencies necessary for CSRD to succeed. Government regulations and reporting guidelines influence CSRD practices, for example, applying sanctions if no action is taken (Gopalan and Kamalnath, 2015), but within the situation in Libya, this is not evident. While these findings are in line with several previous studies (for example, Amran and Devi, 2008; Islam and Deegan, 2008; Pedersen et al., 2013), which indicate that the government has some influence on companies to participate in the RSC contradicts the negative influence evidence of Dam and Scholtens (2012). 
Local companies that have business partners abroad are also exposed to some extent to the awareness of Western CSR. While the presence of a foreign partner in Libya influences the practices of accounting information and corporate disclosure, it can be argued that such influence is temporary to meet the demands of its international stakeholders. In such a situation, and in the light of the absence of well-developed and implemented policies for local businesses and the absence of a complete and formal institutional agreement, business partners abroad help improve CSR. This result is consistent with the findings of previous studies (Amran and Devi, 2008; Amran and Haniffa, 2011) that identify some influences of foreign partners in local businesses in Malaysia. In addition, due to relatively informal weak coercive pressures within the Libyan context (only guidelines have been issued), some managers mimic the strategy of other foreign-owned companies in terms of CSRD to achieve legitimacy. This finding is in line with previous studies (Beddewela and Herzig, 2013; Islam and Deegan, 2008) that have determined that companies are sensitive to what their peers do and that mimetic pressure could be more significant than coercive pressures.

While civil society organizations that can pressure companies to reveal their CSR information are still absent in the country, the need to maintain the reputation and pressures of companies to meet social expectations has been identified as social drivers for the adoption of CSR. Societies generally pressure commercial companies to participate in the CSRD, although with a soft focus. However, managers of oil and gas companies that employ CSRD are trying to achieve ethical legitimacy that reflects not only the cultural values of nations, but also their economic and political interests. By adopting the CSRD, which the main institutional actors consider "the right thing", companies are trying to impact the ethical judgments of those actors. As such, the findings mean once again that CSRD is used as a continuous means to manage the reputation and image of a company, and meet the expectations of society, which are in line with the findings of previous studies (Belal et al., 2015; Kolk, 2004; Zhao and Patten, 2016). 
The study also highlights that due to the observed lack of CSRD framework, enforcement and compliance issues, excessive political instability, corporate governance characteristics namely parent company factor, firm size and age play a significant role in ensuring reporting accountability and disclosure of CSR information. Although subsidiary firms are connecting their long-term strategies with those of the Libyan state, CSRD practices of foreign firms are influenced by international stakeholders - moderated by parent company policy - to a bigger extent than just by local stakeholders. This perhaps as a consequence of their reliance on ongoing access to resources such as; technology, knowledge, and capital (Kostova \& Roth, 2002). Firm age and size also found to play a pivotal role in guaranteeing good practices, transparency, and accountability. Large and big size firms found to reflect higher levels of CSRD which government desires. While age reflects relationships in developed countries, the significance of the institutional relationships is bigger in developing economies, because of the on-going administrative involvement in the economy (Elamer et al., 2018; Elamer et al., 2018; Elamer \& Benyazid, 2018; Elamer et al., 2019; Elamer et al., 2017; Shinkle \& Kriauciunas, 2010), thus, have high legitimacy, because of the longevity of ties with government officials (Shinkle \& Kriauciunas, 2010). These findings are consistent with previous studies in the case of size (Elamer et al., 2018; Elamer et al., 2018; Elamer \& Benyazid, 2018; Elamer et al., 2019; Elamer et al., 2017; Khan et al., 2013; Reverte, 2009), and age (Sufian, 2012).

Although the CSRD in Libya seems to be influenced by national and organizational influences, which are also open to local and global legitimizing forces, manifested in some coercive, normative and mimetic pressures, as illustrated in Figure 2, existing studies (Alshbili, 2016; Mashat, 2005), shows that the level of CSRD is generally low and unsatisfactory. Despite this, in general, the manifestation of the implementation of the CSRD in Libya is mainly a function of different institutional and cultural pressures, that is, coercive, normative and mimetic pressures for the search for legitimacy. These results are somewhat similar to Nurunnabi (2015a) and Nurunnabi (2015b), who concluded that the three pressures of institutional isomorphism (DiMaggio and Powell 1983, 1991) were intertwined in the 
configuration of the implementation of institutional practices in country contexts in development in general, and in Zhao and Patten (2016) in the area of CSRD particularly.

INSERT FIGURE 2 ABOUT HERE

\section{Conclusion}

CSRD practices in Libya are considerably influenced not only by institutional frameworks within the country, but also by organizational and social factors that are also open to local and global legitimizing forces. This is in line with previous literature that supports the link between the national interests of the country and the corporate ownership structure that influences disclosure practices. We also discovered that although Libya has several established guidelines and several factors influence disclosure practices, significant deficiencies in the regulatory framework and legal system remain key issues that must be issued to reflect the dynamic nature of the world market.

Despite managers perceive some coercive, mimetic and normative pressures interplay to influence CSRD to attain legitimacy, the regulations of CSRD are still absent. Thus, in order to improve performance of the accounting and disclosure practices in Libya, the NOC through its human resources and sustainable development departments should put in place monitoring and enforcement roles efficiently. Even though Libya has established several guidelines, it must be emphasised that without an effective monitoring institutions that implement accounting regulations and revision of firms' laws and policies, CSRD practices will not be improved as the guidelines alone is not the solution. Although in the light of the absence of law enforcement and its fragile state environment (Boduszyński \& Pickard, 2013), political instability (Chivvis \& Martini, 2014), the uncertainty to what degree official regulations 
would be useful in this respect, policy and decision makers should consider whether emerging pressure from groups such as civil society organisations become adequately structured and powerful enough to propel firms towards social disclosure leading to an increased level of accounting reporting and disclosure practices. Despite it is questionable whether implementing official regulations, at least in the short run, will enable the state to obtain the official objectives of CSRD, we recommend that monitoring institutions, revision of the firms' laws and policies, the establishment of CSRD regulations should be undertaken to improve accounting disclosure.

This research contributes to knowledge in several ways. First, this research is one of the few studies to use neo-institutional theory (DiMaggio \& Powell, 1983; Meyer \& Rowan, 1977; Scott, 1987, 2014) to contribute to the literature towards understanding how different factors combine in the initiation of CSRD in a fragile state. It explored how such institutional context acts as pressures for CSRD adoption, thus, highlighting how institutional isomorphism is intensely interrelated within the framework of the cultural values of the societal system and national context (Nurunnabi, 2015a). Second, and in contrast to previous studies (Amran \& Devi, 2008; Amran \& Haniffa, 2011; Ntim \& Soobaroyen, 2013) which tend to entirely concentrate on examining company level determinants, this research examined both the impact of external and internal institutional contextual factors on CSRD practices. Therefore, using neo-institutional theory allowed for a more precise grasp and/or understanding of CSRD implementation issues in a specific institutional setting by explaining how companies function, and the extent to which structures and guidelines are influenced by their institutional settings. Finally, the results of this study might be useful to corporate regulators and policy makers in developing a more focussed agenda of CSRD activity, when considering regulations for disclosure.

Despite the results and contributions highlighted above, this research, however, has a number of limitations. First, the review of CSRD practices with Libya as a case has the possibility of offering unique information on the context of the countries of North Africa, especially in light 
of recent changes, but it can generate several risks by generalizing (Bryman, 2016). Perhaps using more extensive research on more states using the institutional profile of each country, the extent to which the findings of current research could be transmitted to other states in North Africa could have been more applicable in this context. Second, this research is limited only to the oil and gas industry, therefore; Investigating other industries and classifying differences in CSRD practices due to industry differences could be possible and valuable. 


\section{References}

Adhikariparajul, M., Hassan, A., Fletcher, M., \& Elamer, A. A. (2019). Integrated reporting in UK higher education institutions. Sustainability Accounting, Management and Policy Journal, Forthcoming. doi:10.1108/SAMPJ-03-2018-0093

Ali, M. A. M., \& Ruhaya, H. A. (2013). The Relationship between Corporate Governance and Corporate Social Responsibility Disclosure: A Case of High Malaysian Sustainability Companies and Global Sustainability Companies. South East Asia Journal of Contemporary Business, Economics and Law, 3(1), 39-48.

Alnabsha, A., Abdou, H. A., Ntim, C. G., \& Elamer, A. A. (2018). Corporate boards, ownership structures and corporate disclosures: Evidence from a developing country. Journal of Applied Accounting Research, 19(1), 20-41.

Alnabsha, A., Abdou, H. A., Ntim, C. G., \& Elamer, A. A. (2018). Corporate boards, ownership structures and corporate disclosures: Evidence from a developing country. Journal of Applied Accounting Research, 19(1), 20-41.

Alshbili, I. A. M. (2016). An Investigation into Corporate Social Responsibility Disclosure in the Libyan Oil and Gas Industry Using a Mixed-Methods Design: An Institutional Perspective. (PhD), University of Huddersfield, Huddersfield, UK.

Alshbili, I., Elamer, A. A., \& Beddewela, E. (2019). Ownership types, corporate governance and corporate social responsibility disclosures: Empirical evidence from a developing country. Accounting Research Journal, Forthcoming. doi:10.1108/ARJ-03-2018-0060

Amran, A., \& Devi, S. S. (2008). The Impact of Government and Foreign Affiliate Influence on Corporate Social Reporting: The Case of Malaysia. Managerial Auditing Journal, 23(4), 386-404.

Amran, A., \& Haniffa, R. M. (2011). Evidence in Development of Sustainability Reporting: A Case of a Developing Country. Business strategy and the environment, 20(3), 141-156.

Bailey, B. C., \& Peck, S. I. (2013). Boardroom Strategic Decision-Making Style: Understanding the Antecedents. Corporate Governance: An International Review, 21(2), 131-146.

Barakat, F. S., Pérez, M. V. L., \& Ariza, L. R. (2015). Corporate Social Responsibility Disclosure (Csrd) Determinants of Listed Companies in Palestine (Pxe) and Jordan (Ase). Review of Managerial Science, 9(4), 681-702.

Barrena Martínez, J., López Fernández, M., \& Romero Fernández, P. M. (2016). Corporate social responsibility: Evolution through institutional and stakeholder perspectives. European Journal of Management and Business Economics, 25(1), 8-14.

Beddewela, E., \& Herzig, C. (2013). Corporate Social Reporting by Mnc's Subsidiaries in Sri Lanka. Accounting Forum, 37(2), 135-149.

Belal, A. R., \& Owen, D. L. (2007). The Views of Corporate Managers on the Current State of, and Future Prospects for, Social Reporting in Bangladesh: An Engagement-Based Study. Accounting, Auditing and Accountability Journal, 20(3), 472-494.

Belal, A. R., Abdelsalam, O., \& Nizamee, S. S. (2015). Ethical Reporting in Islami Bank Bangladesh Limited (1983-2010). Journal of Business Ethics, 129(4), 769-784.

Boduszyński, M. P., \& Pickard, D. (2013). Libya Starts from Scratch. Journal of Democracy, 24(4), 86-96. Bryman, A. (2016). Social Research Methods (5th ed.). Oxford, UK: Oxford university press.

Campbell, J. L. (2004). Institutional change and globalization. Retrieved from https://books.google.co.uk/books?hl=en\&lr=\&id=KX718Sm2- 
nYC\&oi=fnd\&pg=PP11\&dq=Campbell,++2004\&ots=thcUH_nxVa\&sig=9Z-

uMn4Kk4ArVhx9u5FqDVmqKQY\#v=onepage \&q=Campbell\%2C 2004\&f=false

Campbell, J. L. (2007). Why would corporations behave in socially responsible ways? an institutional theory of corporate social responsibility. Academy of Management Review, 32(3), 946-967.

Chivvis, C. S., \& Martini, J. (2014). Libya after Qaddafi: Lessons and Implications for the Future (0833084909). Retrieved from Washington, US:

Dacin, M. T. (1997). Isomorphism In Context: The Power And Prescription Of Institutional Norms. Academy of Management Journal, 40(1), 46-81.

Dam, L., \& Scholtens, B. (2012). Does Ownership Type Matter for Corporate Social Responsibility? Corporate Governance: An International Review, 20(3), 233-252.

Deegan, C. (2002). Introduction: The Legitimising Effect of Social and Environmental Disclosures-a Theoretical Foundation. Accounting, Auditing \& Accountability Journal, 15(3), 282-311.

Deegan, C., \& Blomquist, C. (2006). Stakeholder influence on corporate reporting: An exploration of the interaction between WWF-Australia and the Australian minerals industry. Accounting, Organizations and Society, 31(4-5), 343-372.

Dhaliwal, D., Li, O. Z., Tsang, A., \& Yang, Y. G. (2014). Corporate Social Responsibility Disclosure and the Cost of Equity Capital: The Roles of Stakeholder Orientation and Financial Transparency. Journal of Accounting and Public Policy, 33(4), 328-355.

Dillard, J. F., Rigsby, J. T., \& Goodman, C. (2004). The making and remaking of organization context. Accounting, Auditing \& Accountability Journal, 17(4), 506-542.

DiMaggio, P. J., \& Powell, W. W. (1983). The Iron Cage Revisited: Institutional Isomorphism and Collective Rationality in Organizational Fields. American Sociological Review, 48(2), 147-160.

DiMaggio, P. J., \& Powell, W. W. (1991). The New Institutionalism in Organizational Analysis (Vol. 17): University of Chicago Press Chicago, IL.

Doh, J. P., \& Guay, T. R. (2006). Corporate Social Responsibility, Public Policy, and NGO Activism in Europe and the United States: An Institutional-Stakeholder Perspective. Journal of Management Studies, 43(1), 47-73.

Elamer, A. A., \& Benyazid, I. (2018). The impact of risk committee on financial performance of UK financial institutions. International Journal of Accounting and Finance, 8(2), 161-180.

Elamer, A. A., AlHares, A., Ntim, C. G., \& Benyazid, I. (2018). The corporate governance-risk-taking nexus: Evidence from insurance companies. International Journal of Ethics and Systems, 34(4), 493-509.

Elamer, A. A., AlHares, A., Ntim, C. G., Benyazid, I. J. I. J. o. E., \& Systems. (2018). The corporate governance-risk-taking nexus: evidence from insurance companies. 34(4), 493-509.

Elamer, A. A., Ntim, C. G., \& Abdou, H. A. (2017). Islamic governance, national governance, and bank risk management and disclosure in MENA countries. Business \& Society, Forthcoming.

Elamer, A. A., Ntim, C. G., Abdou, H., Zalata, A., \& Elmagrhi, M. H. (2019). The impact of multi-layer governance on bank risk disclosure in emerging markets: The case of Middle East and North Africa. Accounting Forum, Forthcoming.

Eljayash, K. M. (2015). Documentation of Environmental Disclosure Practices in the Oil Companies in the Countries of the Arab Spring - Some Evidences from Egypt, Libya and Tunisia. Journal of Economics, Business and Management, , 3 (10), 954-960.

Elmagrhi, M. H., Ntim, C. G., Elamer, A. A., \& Zhang, Q. (2019). A study of environmental policies and regulations, governance structures and environmental performance: The role of female directors. Business Strategy and the Environment, 28(1), 206-220. 
Fernández-Alles, M., \& Valle-Cabrera, R. (2006). Reconciling institutional theory with organizational theories. Journal of Organizational Change Management, 19(4), 503-517.

Frynas, J. G., \& Yamahaki, C. (2016). Corporate social responsibility: review and roadmap of theoretical perspectives. Business Ethics: A European Review, 25(3), 258-285.

Fuenfschilling, L., \& Truffer, B. (2014). The structuration of socio-technical regimes-Conceptual foundations from institutional theory. Research Policy, 43(4), 772-791.

Gallego-Álvarez, I., \& Quina-Custodio, I. A. (2017). Corporate Social Responsibility Reporting and Varieties of Capitalism: an International Analysis of State-Led and Liberal Market Economies. Corporate Social Responsibility and Environmental Management, 24(6), 478-495.

Gerged, A. M., Cowton, C. J., \& Beddewela, E. S. (2018). Towards Sustainable Development in the Arab Middle East and North Africa Region: A Longitudinal Analysis of Environmental Disclosure in Corporate Annual Reports. Business Strategy and the Environment, 27(4), 572-587.

Gopalan, S., \& Kamalnath, A. (2015). Mandatory Corporate Social Responsibility as a Vehicle for Reducing Inequality: An Indian Solution for Piketty and the Millennials. Nw. JL \& Soc. Pol'y, 10(1), 34-129.

Gray, R., Kouhy, R., \& Lavers, S. (1995). Methodological Themes: Constructing a Research Database of Social and Environmental Reporting by Uk Companies. Accounting, Auditing \& Accountability Journal, 8(2), 78-101.

Grecco, M. C. P., Milani Filho, M. A. F., Segura, L. C., Sanchez, I.-M. G., \& Dominguez, L. R. (2013). The Voluntary Disclosure of Sustainable Information: A Comparative Analysis of Spanish and Brazilian Companies. Journal of Accounting and Organizations, 7(17), 45-55.

Greenwood, R., Oliver, C., Suddaby, R., \& Sahlin, K. (2013). The Sage Handbook of Organizational Institutionalism (2nd ed.). Los Angeles: SAGE.

Hawashe, A. (2014). An Evaluation of Voluntary Disclosure in the Annual Reports of Commercial Banks: Empirical Evidence from Libya. ( $\mathrm{PhD}$ thesis), University of Salford, Salford, UK.

Hiss, S. (2009). From Implicit to Explicit Corporate Social Responsibility: Institutional Change as a Fight for Myths. Business Ethics Quarterly, 19(3), 433-451.

Hosen, Y. K., Hui, W. S., Suliman, S., \& Rahman, I. A. (2011). Use of Management Control Systems among Libyan Small and Medium-Sized Firms. Asian Journal of Business Management Studies, 2(3), 135143.

Hossain, M. M. (2012). Drivers and Barriers of Corporate Social and Environmental Reporting (Cser) Practices in a Developing Country: Evidence from Bangladesh. (PhD), Curtin University.

Islam, M. A., \& Deegan, C. (2008). Motivations for an Organisation within a Developing Country to Report Social Responsibility Information: Evidence from Bangladesh. Accounting, Auditing \& Accountability Journal, 21(6), 850-874.

Jackson, G., \& Apostolakou, A. (2010). Corporate Social Responsibility in Western Europe: An Institutional Mirror or Substitute? Journal of Business Ethics, 94(3), 371-394.

Jamali, D. (2007). The Case for Strategic Corporate Social Responsibility in Developing Countries. Business and Society Review, 112(1), 1-27.

Jamali, D., Lund-Thomsen, P., \& Khara, N. (2017). CSR Institutionalized Myths in Developing Countries. Business \& Society, 56(3), 454-486.

Kemp, M. (2001). Corporate Social Responsibility in Indonesia: Quixotic Dream or Confident Expectation? Retrieved

04/05/2016 http://www.unrisd.org/80256B3C005BCCF9/search/EF8F86E50D18E6D480256B61005AE53A?

OpenDocument 
Khan, Muttakin, M. B., \& Siddiqui, J. (2013). Corporate Governance and Corporate Social Responsibility Disclosures: Evidence from an Emerging Economy. Journal of Business Ethics, 114(2), 207-223.

Kim, C. H., Amaeshi, K., Harris, S., \& Suh, C.-J. (2013). Csr and the National Institutional Context: The Case of South Korea. Journal of Business Research, 66(12), 2581-2591.

King, N., \& Horrocks, C. (2010). Interviews in Qualitative Research (2 ed.). London: Sage Publications.

Kolk, A. (2004). A Decade of Sustainability Reporting: Developments and Significance. International Journal of Environment and Sustainable Development, 3(1), 51-64.

Kostova, T., \& Roth, K. (2002). Adoption of an Organizational Practice by Subsidiaries of Multinational Corporations: Institutional and Relational Effects. Academy of Management Journal, 45(1), 215233.

Luetkenhorst, W. (2004). Corporate Social Responsibility and the Development Agenda. Intereconomics, 39(3), 157-166.

Mashat, A. A. (2005). Corporate Social Responsibility Disclosure and Accountability: The Case of Libya. $(\mathrm{PhD})$, Manchester Metropolitan University, Manchester, UK.

Meyer, J. W., \& Rowan, B. (1977). Institutionalized Organizations: Formal Structure as Myth and Ceremony. American Journal of Sociology, 340-363.

Miles, M. B., \& Huberman, A. M. (1994). Qualitative Data Analysis: An Expanded Sourcebook. Thousand Oaks, Calif; London: Sage.

NOC, N. O. C. (2012). The Sustainable Development Department Report. Retrieved from Tripoli, Libya:

Ntim, C. G., \& Soobaroyen, T. (2013). Corporate Governance and Performance in Socially Responsible Corporations: New Empirical Insights from a Neo-Institutional Framework. Corporate Governance: An International Review, 21(5), 468-494.

Ntim, C. G., Lindop, S., Osei, K. A., \& Thomas, D. A. (2015). Executive Compensation, Corporate Governance and Corporate Performance: A Simultaneous Equation Approach. Managerial and Decision Economics, 36(2), 67-96.

Nurunnabi, M. (2015a). The Impact of Cultural Factors on the Implementation of Global Accounting Standards (Ifrs) in a Developing Country. Advances in Accounting, 31(1), 136-149.

Nurunnabi, M. (2015b). Tensions between Politico-Institutional Factors and Accounting Regulation in a Developing Economy: Insights from Institutional Theory. Business Ethics: A European Review, 24(4), 398-424.

Othman, S., Darus, F., \& Arshad, R. (2011). The Influence of Coercive Isomorphism on Corporate Social Responsibility Reporting and Reputation. Social Responsibility Journal, 7(1), 119-135.

Pedersen, E. R. G., Neergaard, P., Pedersen, J. T., \& Gwozdz, W. (2013). Conformance and Deviance: Company Responses to Institutional Pressures for Corporate Social Responsibility Reporting. Business strategy and the environment, 22(6), 357-373.

Perez-Batres, L. A., Doh, J. P., Miller, V. V., \& Pisani, M. J. (2012). Stakeholder Pressures as Determinants of CSR Strategic Choice: Why do Firms Choose Symbolic Versus Substantive Self-Regulatory Codes of Conduct? Journal of Business Ethics, 110(2), 157-172.

Powell, J. J. W., \& Solga, H. (2010). Analyzing the nexus of higher education and vocational training in Europe: a comparative-institutional framework. Studies in Higher Education, 35(6), 705-721.

Powell, W. W., \& DiMaggio, P. (2012). The New institutionalism in organizational analysis. Retrieved from https://books.google.co.uk/books?hl=en\&lr=\&id=jbTbAgAAQBAJ\&oi=fnd\&pg=PR5\&dq=Powel 1+and+DiMaggio,+2012\&ots=pDjjBcH18I\&sig=SHD29v8w62Ad036bEXdsskAtG2s\#v=onepage $\& q=$ Powell and DiMaggio\%2C 2012\&f=false 
Reverte, C. (2009). Determinants of Corporate Social Responsibility Disclosure Ratings by Spanish Listed Firms. Journal of Business Ethics, 88(2), 351-366.

Schultz, F., \& Wehmeier, S. (2010). Institutionalization of corporate social responsibility within corporate communications. Corporate Communications: An International Journal, 15(1), 9-29.

Scott, W. R. (1987). The Adolescence of Institutional Theory. Administrative science quarterly, 32, 493-511.

Scott, W. R. (2014). Institutions and Organizations. Ideas, Interests and Identities (4th ed.). London, UK: Sage Publications, Inc.

Setyorini, C. T., \& Ishak, Z. (2012). Corporate Social and Environmental Reporting: A Case of Mimetic Isomorphism. American International Journal of Contemporary Research, 2(5), 11-17.

Shareia, B. F. (2014). The Libyan Accounting Profession. International Journal of Social, Behavioral, Educational, Economic and Management Engineering 8(12), 3623-3631

Shinkle, G. A., \& Kriauciunas, A. P. (2010). Institutions, Size and Age in Transition Economies: Implications for Export Growth. Journal of International Business Studies, 41(2), 267-286.

Siggelkow, N. (2007). Persuasion with Case Studies. Academy of management journal, 50(1), 20-24.

Sufian, M. A. (2012). Corporate Social Responsibility Disclosure in Bangladesh. Global Journal of Management and Business Research, 12(14), 148-155.

Sumiani, Y., Haslinda, Y., \& Lehman, G. (2007). Environmental reporting in a developing country: a case study on status and implementation in Malaysia. Journal of Cleaner Production, 15(10), 895-901.

The World FactBook, C. I. A. (2016). The World Factbook, Africa, Libya. Retrieved 29/02/2016, from Central Intelligence Agency https://www.cia.gov/library/publications/the-worldfactbook/geos/ly.html

Wanderley, L. S. O., Lucian, R., Farache, F., \& de Sousa Filho, J. M. (2008). Csr Information Disclosure on the Web: A Context-Based Approach Analysing the Influence of Country of Origin and Industry Sector. Journal of Business Ethics, 82(2), 369-378.

Welford, R. (2005). Corporate Social Responsibility in Europe, North America and Asia. Journal of Corporate Citizenship, 2005(17), 33-52.

World Bank, W. (2016). Country at a Glance, Libya Retrieved 18/03/2016 http://sdwebx.worldbank.org/climateportalb/home.cfm?page=country_profile\&CCode=LBY

Zhao, N., \& Patten, D. M. (2016). An Exploratory Analysis of Managerial Perceptions of Social and Environmental Reporting in China: Evidence from State-Owned Enterprises in Beijing. Sustainability Accounting, Management and Policy Journal, 7(1), 80-98. 
Table 1: The Legal and Regulatory Framework in Libya

\begin{tabular}{|c|c|c|c|}
\hline $\begin{array}{l}\text { Name of the institution } \\
\text { and/or law }\end{array}$ & Key aspects & $\begin{array}{l}\text { Relevant to firms } \\
\text { working in the oil } \\
\text { industry }\end{array}$ & $\begin{array}{l}\text { Require } \\
\text { (Yes/No) }\end{array}$ \\
\hline The NOC & $\begin{array}{l}\text { - Updating the HSE.POL.000.00. Establishment of HSE.GDL.001.00 \& } \\
\text { HSE.PRO.002.00 social responsibility monitoring reporting requirements } \\
\text { guidelines (NOC Department, 2014). } \\
\text { - Establishment of the sustainable development department to encourage firms to } \\
\text { engage in CSR and its disclosure }\end{array}$ & Yes & Yes \\
\hline $\begin{array}{l}\text { The Libyan Commercial } \\
\text { Activity Law No } 23 \text { of } \\
2010\end{array}$ & $\begin{array}{l}\text { - The number of board members has not been specified. } \\
\text { - } \quad \text { Board members are required to meet at least six times a year. } \\
\text { - The General Assembly assesses the firm responses to the Public Control Office } \\
\text { comments on the annual reports. } \\
\text { - State-owned companies or joint venture firms are required to possess the } \\
\text { subsequent records "a minute record of the meetings of the board directors and } \\
\text { its decisions, a minute record of the monitoring committee's meetings and its } \\
\text { decisions, a minute record of the meetings of the executive committee and its } \\
\text { decisions". }\end{array}$ & Yes & $\begin{array}{l}\text { No articles within this } \\
\text { law refer to CSRD. }\end{array}$ \\
\hline $\begin{array}{l}\text { The Libyan Corporate } \\
\text { Governance Code } 2005\end{array}$ & $\begin{array}{l}\text { - Part one - the essence of corporate governance and its significance in reducing } \\
\text { the conflict of interest between parties. } \\
\text { Part two - the criteria of the board, how they should perform their duties } \\
\text { regarding the rights of shareholders, access to information, the attendance of the } \\
\text { general meeting, voting rights. } \\
\text { Part three - the choice of management and its supervisory role including an } \\
\text { explanation of the most important tasks of the board of directors. } \\
\text { - Part four - planning and policy formulations including a description of the } \\
\text { responsibilities of the board of directors and the formulations and monitoring of } \\
\text { policies and plans. } \\
\text { Part five - auditing and internal control. All companies must develop procedures } \\
\text { and policies of disclosure and supervisory regulations in written forms consistent } \\
\text { with the LCGC rules. }\end{array}$ & $\begin{array}{l}\text { It is voluntary but } \\
\text { companies are } \\
\text { asked to "comply- } \\
\text { or-explain" basis. }\end{array}$ & $\begin{array}{l}\text { No articles within this } \\
\text { law refer to CSRD. }\end{array}$ \\
\hline
\end{tabular}


Figure 1: Theoretical Framework for the Current Study

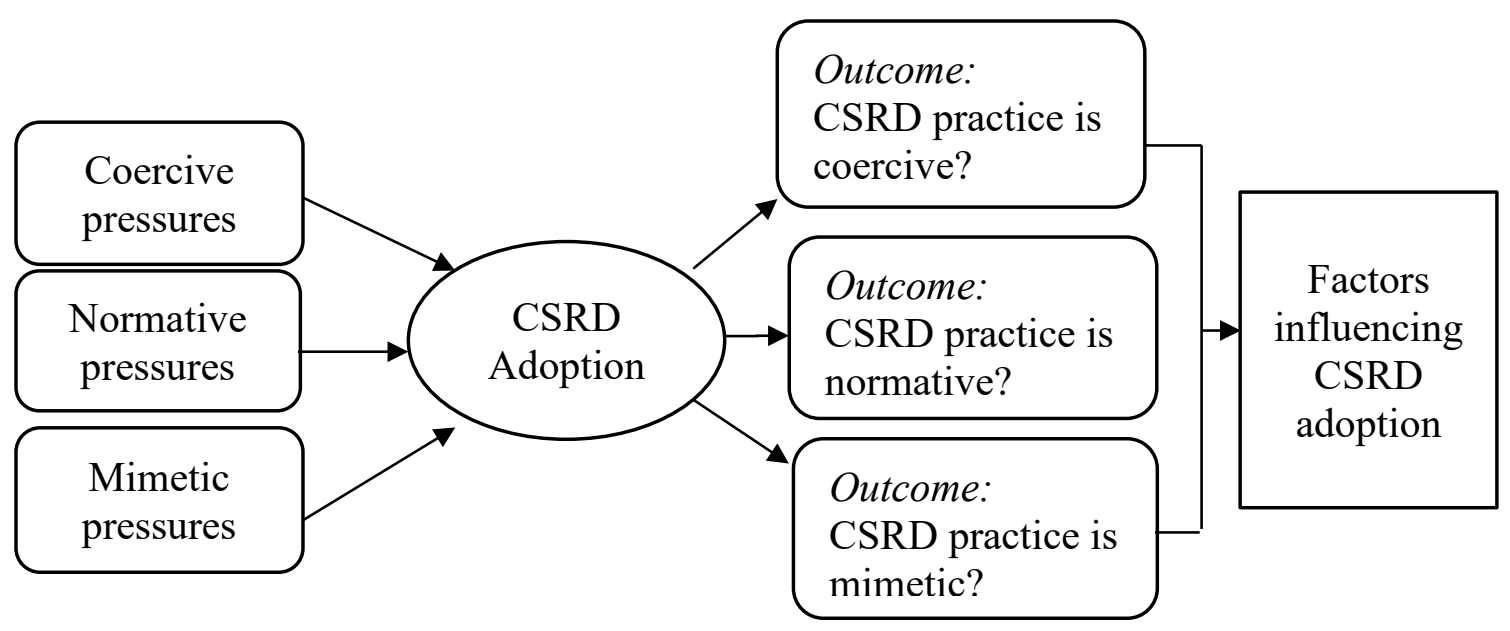


Table 2: Profile of the Interviewees (Companies oil and gas managers)

\begin{tabular}{|c|c|c|c|c|c|c|}
\hline Case & Firms & $\begin{array}{l}\text { Code for the } \\
\text { interviewee }\end{array}$ & $\begin{array}{l}\text { Firm } \\
\text { type }\end{array}$ & $\begin{array}{l}\text { Profession of } \\
\text { interviewee }\end{array}$ & Gender & $\begin{array}{l}\text { Duration of } \\
\text { the interview }\end{array}$ \\
\hline 1 & A & Company 1 & $\mathrm{~L}^{1}$ & Financial manager & $\mathrm{M}$ & 73 minutes \\
\hline 2 & B & Company 1 & $\mathrm{JV}^{2}$ & $\begin{array}{l}\text { Head of health, } \\
\text { safety and } \\
\text { Environment }\end{array}$ & M & 57 minutes \\
\hline 3 & A & Company 1 & $\mathrm{~L}$ & Quality manager & M & 51 minutes \\
\hline 4 & $\mathrm{C}$ & Company 2 & $\mathrm{~L}$ & Accounts manager & M & 64 minutes \\
\hline 5 & $\mathrm{D}$ & Company 2 & JV & $\begin{array}{l}\text { Communication } \\
\text { manager }\end{array}$ & $\mathrm{F}$ & 46 minutes \\
\hline 6 & $\mathrm{E}$ & Company 1 & $\mathrm{~F}^{3}$ & $\begin{array}{l}\text { Head of health, } \\
\text { safety and } \\
\text { Environment }\end{array}$ & M & 48 minutes \\
\hline 7 & $\mathrm{~F}$ & Company 3 & JV & Financial manager & M & 58 minutes \\
\hline 8 & G & Company 4 & JV & $\begin{array}{l}\text { Environmental } \\
\text { manager }\end{array}$ & M & 61 minutes \\
\hline 9 & $\mathrm{H}$ & Company 5 & JV & $\begin{array}{l}\text { Head of accounts } \\
\text { and budget }\end{array}$ & M & 65 minutes \\
\hline 10 & I & Company 2 & $\mathrm{~F}$ & Director of finance & M & 53 minutes \\
\hline 11 & $\mathrm{~J}$ & Company 3 & $\mathrm{~F}$ & $\begin{array}{l}\text { Head of health, } \\
\text { safety and } \\
\text { Environment }\end{array}$ & M & 68 minutes \\
\hline 12 & $\mathrm{~K}$ & Company 3 & $\mathrm{~L}$ & $\begin{array}{l}\text { Environmental } \\
\text { manager }\end{array}$ & M & 51 minutes \\
\hline 13 & $\mathrm{~L}$ & Company 4 & $\mathrm{~F}$ & Auditor & $\mathrm{F}$ & 43 minutes \\
\hline 14 & $\mathrm{M}$ & Company 4 & $\mathrm{~L}$ & Auditor & M & 53 minutes \\
\hline
\end{tabular}

\footnotetext{
${ }^{1} \mathrm{~L} \quad=$ Local company

${ }^{2} \mathrm{JV}=$ Joint venture company

${ }^{3} \mathrm{~F}=$ Foreign company
} 
Table 3: Profile of the Interviewees (Policy and decision makers within NOC)

\begin{tabular}{l|llll}
\hline $\begin{array}{l}\text { Name of the } \\
\text { Organisation }\end{array}$ & $\begin{array}{l}\text { Code for the } \\
\text { interviewee }\end{array}$ & $\begin{array}{l}\text { Profession of the } \\
\text { interviewee* }\end{array}$ & $\begin{array}{l}\text { Gender } \\
\text { NOC }\end{array}$ & $\begin{array}{l}\text { Duration of } \\
\text { the interview }\end{array}$ \\
NOC & Interviewee two & - & M & 78 minutes \\
NOC & Interviewee three & - & M & 73 minutes \\
& & M & & 64 minutes \\
NOC & Interviewee four & - & M & 56 minutes \\
NOC & Interviewee five & - & & \\
& & & & 66 minutes \\
NOC & Interviewee six & - & M & 69 Minutes \\
\hline
\end{tabular}

*Note: Interviewee position left blank for confidentiality purposes and replaced by code for the interviewee in the previous column 
Table 4. Codes on factors influncing CSRD adoption

\begin{tabular}{l|l}
\hline First-order coding & Second-order coding \\
\hline NOC & Institutional factors \\
Overseas Partners & \\
Foreign Owned Firms & \\
Parent company factor & \\
Firm size & \\
Firm age & Social/norm Factors \\
Firm's reputation and image. \\
$\begin{array}{l}\text { Pressures to meet societal } \\
\text { expectations. }\end{array}$
\end{tabular}




\section{Table 5: Tracking the Changes within the NOC Pre/Post 2011 Revolution}

The NOC is responsible for the oil and gas operations in Libya, giving licences to companies to operate, being in charge of the implementation of laws and firms settlement, and it is engaged in putting into practice the Social Security Schemes for employees.

\begin{tabular}{|c|c|c|c|}
\hline Pre-2011 & Implemented & Post-2011 & Implemented \\
\hline - Not Establishment & - & $\begin{array}{l}\text { - Establishment of the sustainable } \\
\text { development department to } \\
\text { encourage firms to engage in } \\
\text { CSR and its disclosure. }\end{array}$ & - $\quad$ Yes \\
\hline $\begin{array}{l}\text { - The Petroleum Law } \\
\text { No. } 25 \text { of } 1955 \text { (see } \\
\text { chapter two section } \\
2.64 \text { for more details } \\
\text { about this law) }\end{array}$ & Yes & $\begin{array}{l}\text { - In 2012, the Minister of Oil \& } \\
\text { Gas prepared a draft of a new } \\
\text { law; however the procedure for } \\
\text { issuing the new law has yet to } \\
\text { start. }\end{array}$ & - $\quad$ No \\
\hline $\begin{array}{l}\text { - HSE.POL.000.00 } \\
\text { considering only the } \\
\text { CSR policy. }\end{array}$ & Yes & $\begin{array}{lr}\text { - } & \text { Updating the HSE.POL.000.00. } \\
\text { - } & \text { Establishment } \\
\text { HSE.GDL.001.00 } & \text { of } \\
\text { HSE.PRO.002.00 } & \text { social } \\
\text { responsibility } & \text { monitoring } \\
\text { reporting } & \text { requirements } \\
\text { guidelines (NOC } & \text { Department, } \\
\text { 2014). } & \end{array}$ & - $\quad$ Yes \\
\hline - $\quad$ Not Establishment & - & $\begin{array}{l}\text { - The Minister of Oil \& Gas } \\
\text { issued decision No (32) for the } \\
\text { year } 2012 \text { about making sure } \\
\text { that the oil and gas companies } \\
\text { make the necessary } \\
\text { arrangements for the protection } \\
\text { of the environment, fight against } \\
\text { pollution and the requirements } \\
\text { of public safety. }\end{array}$ & - $\quad$ Yes \\
\hline
\end{tabular}


Figure 2: Multiple Sources of Influence on CSRD, Neo-institutionalism and Outcomes in Libya

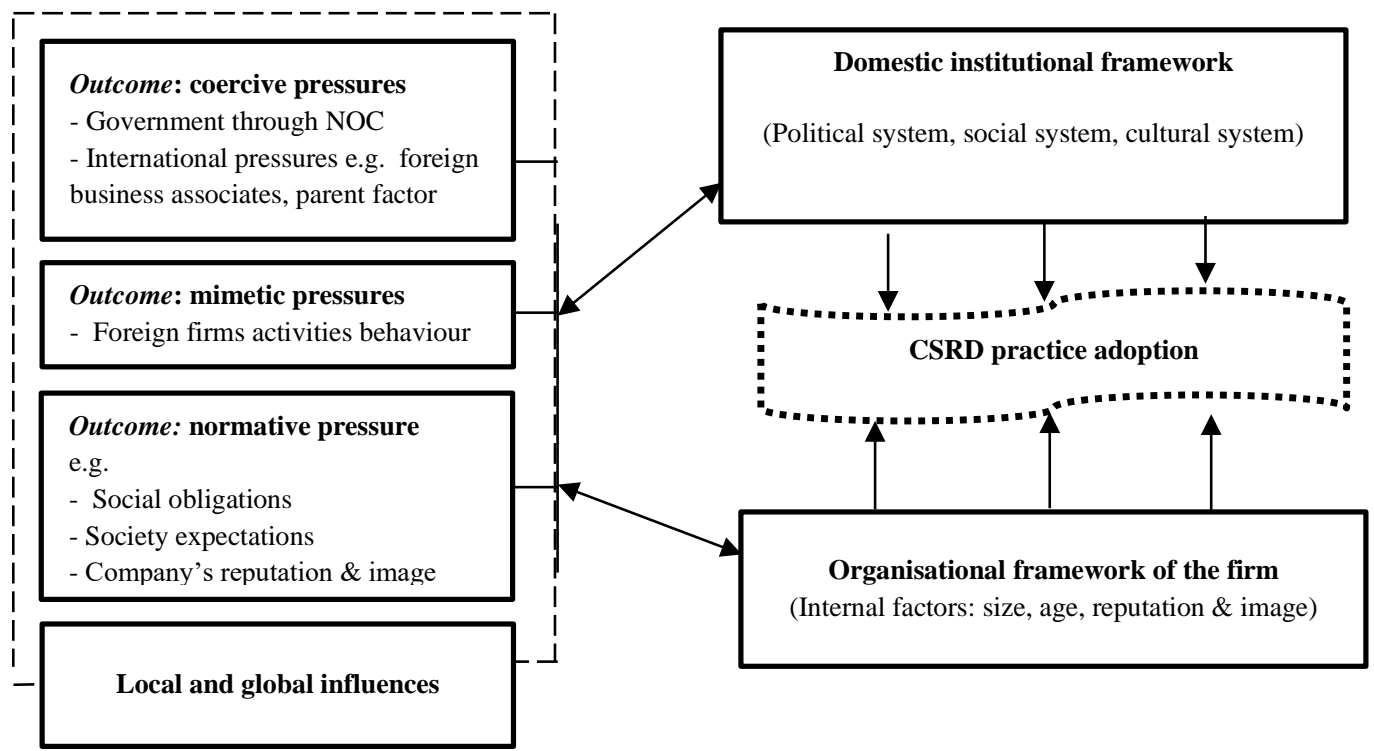

